\title{
PUNGUTAN DANA KRAMA TAMIU BAGI PENDUDUK PENDATANG DI KLUNGKUNG BALI
}

\author{
Hasan \\ Kantor Biro Ibadah Haji Takhobbar TELKOM JI. Ketintang I 56 Surabaya | \\ hasaneeldjuney@gmail.com
}

\begin{abstract}
This article highlights the collection of dana krama tamu (migrant ethic fund) for migrants in Klungkung district, Klungkung-Bali Regency. They are borne dana krama tamu by Banjar Adat / Pakraman which is determined by each Banjar Adat / Pakraman. The withdrawal process of dana krama tamu is done monthly by the security guards of Banjar Adat / Pakraman namely pecalang. While the rights that can be obtained by them are security, health care, shelter from disaster, and the use of facilities of Banjar Adat. However, security is not necessarily be felt by all migrants. In the concept of figh siyasah (Islamic political jurisprudence), it is unknown about dana krama tamu. But in the history of the Islamic governments, there was a concept of jizya. It is a levie which was taken from ahl al-zimmah as a guarenty for their safety. The collection of dana krama tamu is substantially different with that of jizya. But there are some similarities that can be seen, especially from the rights given to them. Thus, the withdrawal of dana krama tamu can be justified because it is not much different from the concept of jizya in historical Muslim community.
\end{abstract}

Keywords: Fund levy, Dana Krama Tamu, Islamic political jurisprudence.

Abstrak: Artikel ini membahas tentang pungutan dana krama tamiu bagi penduduk pendatang di Kec. Klungkung Kab. Klungkung-Bali. Penduduk pendatang di Kec. Klungkung Kab. Klungkung-Bali dikenai pungutan dana krama tamiu oleh Banjar Adat/Desa Pakraman yang besarnya ditentukan oleh masing-masing Banjar Adat/Desa Pakraman. Proses penarikan pungutan dana krama tamiu dilakukan setiap bulan oleh petugas keamanan Banjar Adat/Desa Pakraman yaitu pecalang. Sedangkan hak-hak yang bisa didapatkan oleh mereka adalah jaminan keamanan, pelayanan kesehatan, pengayoman dari bencana, dan penggunaan fasilitas Banjar Adat. Namun, jaminan keamanan tidak 
serta merta dapat dirasakan oleh semua penduduk pendatang. Dalam konsep figh siyasah, tidak dikenal adanya pungutan dana krama tamiu. Akan tetapi dalam sejarah pemerintahan Islam sudah mengenal konsep jizyah, pungutan yang diambil dari ahl al-zimmah sebagai jaminan atas keamanan mereka. Secara substansial pungutan dana krama tamiu dengan jizyah memang berbeda, namun ada beberapa kesamaan yang bisa dilihat, terutama dari hak-hak yang diberikan kepada mereka. Dengan demikian, maka penarikan dana krama tamiu tersebut bisa dibenarkan karena tidak jauh berbeda dengan konsep jizyah dalam Islam.

Kata Kunci: Pungutan dana, Krama Tamiu, fiqh siyasah.

\section{Pendahuluan}

Tragedi Bom Bali 12 Oktober 2002 yang telah membunuh ratusan jiwa, membawa dampak perubahan besar bagi masyarakat Bali khususnya dan Indonesia pada umumnya. Salah satu dari perubahan besar itu adalah adanya pengaturan tentang penduduk pendatang (tamiu). Penduduk pendatang yang bebas kontrol dianggap sebagai salah satu dari penyebab terjadinya tragedi Bom Bali tersebut. Maka, sebagai bentuk memperbaiki tatanan masyarakat Bali ke depan dalam rangka mencapai Tri Hita Karana, ${ }^{1}$ dibuatlah peraturan tertib administrasi tentang penduduk pendatang (tamiu).

Fakta-fakta sejarah menunjukkan bahwa persoalan penduduk pendatang di Bali sesungguhnya bukanlah suatu hal yang baru, sebab keberadaan mereka di Bali sudah ada sejak lama. Sejarah mencatat, rombongan Maharsi Markandya telah datang ke Bali sekitar abad ke-9 untuk membuka hutan dan membangun desadesa Pakraman ${ }^{2}$. Sejarah juga memperlihatkan kedatangan orang-

\footnotetext{
I Tri Hita Karana berarti bahwa kesejahteraan umat manusia didunia ini hanya dapat terwujud bila terjadi keseimbangan hubungan antara unsur-unsur Tuhan-Manusia-Alam. Tri Hita Karana ini bersumber dari ajaran Hindu, yang secara tekstual berarti tiga penyebab kesejahteraan (tri=tiga, hita=kesejahteraan, karana=sebab). Tiga unsur tersebut adalah Sanghyang Jagatkarana (Tuhan Sang Pencipta), Bhuana (alam semesta), dan Manusa (manusia).

${ }^{2}$ Desa Pakraman adalah "kesatuan masyarakat hukum adat di Provinsi Bali yang mempunyai satu kesatuan tradisi dan tata krama pergaulan hidup masyarakat umat Hindu secara turun temurun dalam ikatan Kahyangan Tiga atau Kahyangan Desa yang mempunyai wilayah tertentu dan harta
}

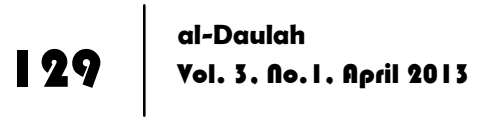


orang muslim yang "diundang" dan dimanfaatkan oleh raja-raja Bali karena keahliannya, yang kemudian dilokalisasi di kawasan tertentu, seperti sekarang dapat dilihat di desa Saren (Buda Keling Karangasem), desa Gelgel (Klungkung) ${ }^{3}$, Pegayaman (Buleleng), dan Kepaon (Denpasar). Tak luput, dalam sejarah kepariwisataan Bali juga terdapat pendatang-pendatang asing pertama yang datang ke Bali untuk berwisata, mulai dari rombongan Cornelis de Houtman (1597), Van Kol (1902), sampai kemudian Bali ramai dikunjungi wisatawan asing setelah beroperasinya kapal perusahan pelayaran milik pemerintah Belanda Koninklijk Paketvart Maatschapij tahun 1920.4

Di masa yang lalu, kehadiran penduduk pendatang ke Bali belum menjadi suatu masalah. Karena Bali yang dulu identik dengan keramahan, digambarkan penuh gairah dan pesona. Budaya dan alamnya saling bertautan erat, tempat tinggal sebuah masyarakat yang mapan dan harmonis. Bahkan jalinan antara agama Hindu dan kebudayaan Bali telah mengendap menjadi suatu keyakinan dalam keseharian orang Bali. Tetapi belakangan ini serbuan penduduk pendatang dengan beragam latar belakang, etnis, profesi, dan tujuan, telah menjadi permasalahan tersendiri yang cukup kompleks bagi Bali, terutama di daerah perkotaan. Baik penduduk pendatang untuk tujuan menetap atau sekedar datang untuk sementara (musiman), karena melakukan suatu perjalanan. Bali yang dulu dikenal dengan damainya bila dibandingkan dengan Bali masa kini seolah menyajikan ketegangan dualisme yang paradoks.

Berbagai permasalahan kependudukan pun mulai muncul dan beragam pula. Seperti kepadatan penduduk yang terus

kekayaan sendiri serta berhak mengurus rumah tangganya sendiri" (Pasal I no urut 4, Perda Provinsi Bali No 3 Tahun 200 I tentang Desa Pakraman).

3 Klungkung adalah kota Islam tertua di Bali. Tepatnya di desa Gelgel inilah pada abad ke sebelas pertama kali kerajaan Majapahit transit dan menyebarkan ajaran Islam. Bahkan berawal dari Desa Gelgel ini pula penyebaran Islam meluas hingga sampai ke Nusa Penida. (Majalah Aula, edisi Mei tahun 2007)

${ }^{4}$ http://www.e-banjar.com/content/view/299 
meningkat, bertambahnya pengangguran, meluasnya kriminalitas, meningkatnya prostitusi, adanya penyalahgunaan narkoba, dan sebagainya telah mengganggu kenyamanan dan keajegan masyarakat Bali sendiri. Hal ini diperparah dengan adanya berbagai permasalahan yang meliputi aspek sosial, ekonomi, politik, budaya dan agama. Namun dari sekian permasalahan yang ada di Bali, masalah kependudukan patut mendapatkan perhatian lebih, karena berhubungan dengan semua aspek kehidupan masyarakat Bali, baik aspek sosial, ekonomi, politik, budaya, maupun aspek agama.

Pemerintah sendiri tampaknya tidak bisa berbuat banyak untuk menghadapi penduduk pendatang ini. Berbagai langkah telah dilakukan, mulai dari mewajibkan penduduk pendatang mempunyai kartu identitas khusus bagi penduduk pendatang (KIPS/STPPTS) dengan biaya yang cukup tinggi sampai langkahlangkah penertiban (inspeksi mendadak/sidak) pada malam hari yang sudah sering dilakukan, tetapi persoalan penduduk pendatang masih sulit untuk diatasi.

Melihat kondisi demikian, maka Gubernur Bali bersama Bupati/Walikota se-Bali mengeluarkan kesepakatan bersama dalam rangka tertib administrasi penduduk pendatang tersebut. Untuk itu, pada hari Senin, tanggal 10 Pebruari 2003 lahirlah kesepakatan bersama Gubernur Bali dengan Bupati/Walikota seBali No. 153 Tahun 2003 tentang pelaksanaan tertib administrasi kependudukan di Propinsi Bali. Kesepakatan bersama yang di tandatangani oleh seluruh Bupati/Walikota bersama Gubernur Bali $^{5}$ ini bersepakat untuk melaksanakan kesepakatan bersama mengenai tertib administrasi kependudukan di masing-masing Kabupaten/Kota dalam wilayah Propinsi Bali dengan mengacu

5 Di antara pejabat yang menandatangani kesepakatan tersebut adalah I. Dewa Beratha (Gubernur Bali), 2. Puspayoga (Walikota Denpasar), 3. A.A. Ngurah Oka Ratmadi (Bupati Badung), 4. Drs. Putu Bagiada, MM (Bupati Buleleng), 5. I Gede Winasa (Bupati Jembrana), 6. N. Adi Wiryatama, S.Sos (Bupati Tabanan), 7. Tjokorda Gde Budi Suryawan, SH (Bupati Gianyar), 8. I Nengah Arnawa (Bupati Bangli), 9. Ir. Tjokorda Gde Ngurah (Bupati Klungkung), I0. I Gede Sumantara Adi Pranata (Bupati Karangasem).

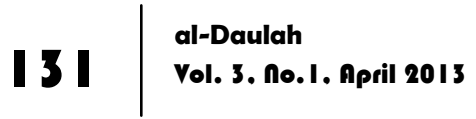


pada surat Gubernur Bali Nomor 470/7587/B. Tapem, tanggal 14 Nopember 2002 perihal pedoman pendaftaran penduduk pendatang.

Yang dimaksud penduduk pendatang dalam kesepakatan ini adalah penduduk yang datang dari luar Propinsi Bali untuk tinggal menetap atau tinggal sementara di propinsi Bali (pasal 1 ayat a). Setiap penduduk pendatang dikenai biaya administrasi sebesar Rp. 50.000,- untuk Kartu Identitas Penduduk Sementara (KIPS) dan Rp. 5.000,- bagi Surat Tanda Pendaftaran Penduduk Tinggal Sementara (STPPTS) sesuai dengan pasal 4 ayat (a) dan (b) dalam kesepakatan bersama tersebut.

Namun, walaupun dikenai biaya administrasi yang cukup besar, permasalahan penduduk pendatang masih cukup sulit untuk diatasi. Bahkan sering ada penentangan dari mereka dengan melaksanakan aksi turun jalan atau unjuk rasa untuk menolak besarnya biaya pungutan KIPS yang diberlakukan. Seperti yang dilakukan oleh warga pendatang di Denpasar. Sekitar 400 orang yang tergabung dalam Komite Perjuangan Rakyat Kecil, pada Senin (6/1), mendatangi Kantor Wali Kota Denpasar untuk memprotes mahalnya biaya pembuatan Kartu Identitas Penduduk Pendatang (KIPS) di Denpasar. Selain itu, mereka juga menyesalkan sikap oknum petugas yang arogan dan kasar, saat pemeriksaan identitas penduduk dilangsungkan. ${ }^{6}$

Melihat kondisi demikian, maka Pemerintah Propinsi Bali mulai memfungsikan peranan desa adat/Pakraman. Akhirnya pengaturan keberadaan penduduk pendatang mulai diserahkan pada desa Pakraman/Banjar adat di daerah masing-masing Kabupaten/Kota di seluruh Propinsi Bali. Tak luput dari pemberlakuan aturan itu juga di Kecamatan Klungkung Kabupaten Klungkung Bali yang memiliki jumlah penduduk pendatang cukup besar.

${ }^{6}$ http://www2.kompas.com/kompas-cetak/030 I/07/daerah/723 I2.htm

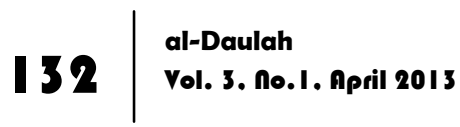


Dengan mengacu pada kesepakatan bersama Gubernur Bali dengan Bupati/Walikota se-Bali No. 153 Tahun 2003 dan instruksi Bupati Klungkung Nomor 268 Tahun 2003 tentang pemberlakuan kesepakatan bersama tersebut, maka dibuatlah petunjuk teknis pelaksanaan pendaftaran penduduk pendatang yang dihasilkan pada rapat kerja Kependudukan Tingkat Kabupaten Klungkung tanggal 1 Juli 2004.

Dalam petunjuk teknis tentang pendaftaran penduduk pendatang di Kabupaten Klungkung tersebut diterangkan tentang kewajiban dan hak setiap penduduk pendatang. Salah satu dari kewajibannya selain membayar biaya administrasi sesuai dengan kesepakatan bersama Gubernur Bali dengan Bupati/Walikota seBali No.153 Tahun 2003, penduduk pendatang juga dipungut dana krama tamiu oleh desa Pakraman/Banjar adat yang besarnya sesuai dengan awig-awig ${ }^{7}$ Banjar adat/desa Pakraman setempat. ${ }^{8}$

Dengan adanya pungutan dana krama tamiu yang ditarik oleh Banjar adat/desa Pakraman melaui Pecalang/Langlang 9 setiap bulannya, maka banyak penduduk pendatang yang mayoritas dari mereka adalah beragama Islam mempertanyakannya, untuk apa

7 Secara umum Awig-awig adalah suatu produk hukum dari suatu organisasi tradisional (banjar adat /desa Pakraman)di Bali, yang umumnya dibuat secara musyawarah mufakat berdasarkan rasa keadilan dan rasa kepatutan oleh seluruh anggotanya dan berlaku sebagai pedoman dan patokan-patokan dalam bertingkah laku dari anggota organisasi yang bersangkutan. Dalam arti khusus, awig-awig diartikan sebagai "aturan yang dibuat oleh krama desa Pakraman dan atau krama banjar Pakraman yang dipakai sebagai pedoman dalam pelaksanaan Tri Hita Karana sesuai dengan desa mawacara dan dharma agama di desa Pakraman/banjar adat masingmasing". Pemberdayaan Awig-awig Menuju Ajeg Bali, Lembaga Dokumentasi dan Publikasi Hukum Universitas Udayana, 2005. Tjok Istri Putra Astiti, Pemberdayaan Awig-awig Menuju Ajeg Bali, (Bali: Lembaga Dokumentasi dan Publikasi Hukum Universitas Udayana, 2005), 19.

${ }^{8}$ Dinas Tenaga Kerja, Kependudukan, dan Catatan Sipil Kab. Klungkung, Petunjuk Teknis Tentang Pelaksanaan Pendaftaran Penduduk Pendatang Di Kabupaten Klungkung, 3 .

9 Pacalang atau Langlang adalah satgas (satuan tugas) keamanan tradisional masyarakat Bali yang mempunyai tugas dan wewenang untuk menjaga keamanan dan ketertiban wilayah, baik ditingkat banjar dan atau di wilayah Desa Pakraman. Pacalang melaksanakan tugas-tugas pengamanan dalam wilayah Desa Pakraman dalam hubungan pelaksanaan tugas agama dan adat serta acara-acara penting lainnya apabila dimohon oleh instansi/lembaga resmi dan sesuai pararem Desa Pakraman. Pacalang diangkat/dipilih dan diberhentikan oleh Desa Pakraman / Banjar Adat berdasarkan paruman desa serta persyaratan dan sesana maupun busana diatur di dalam awig-awig/pararem Desa Pakraman. 
Dana krama tamiu tersebut dipergunakan? Mereka beranggapan bahwa pungutan Dana krama tamiu tersebut sebagai suatu bentuk diskriminasi bagi mereka.

Kegelisahan penduduk pendatang tentang adanya pungutan Dana krama tamiu tersebut, mengundang penulis untuk melakukan studi penelitian tentang permasalahan tersebut.

\section{Dana Krama Tamiu bagi Penduduk Pendatang di Kec. Klungkung Kab. Klungkung - Bali}

Kecamatan Klungkung merupakan kecamatan terkecil dari 4 (empat) Kecamatan yang ada di Kabupaten Klungkung. Dengan luas wilayah mencapai 2.095 Ha dan dengan batas-batas sebagai berikut :

a. Sebelah Utara adalah Kabupaten Karangasem.

b. Sebelah Timur adalah Kecamatan Dawan.

c. Sebelah Barat adalah Kecamatan Banjarangkan.

d. Sebelah Selatan adalah Selat Badung.

Secara administrasi pemerintahan Kecamatan Klungkung terdiri dari 12 desa, 6 kelurahan, dan 59 dusun/lingkungn. Jumlah penduduknya 57.661 jiwa yang terdiri dari 28.553 jiwa laki-laki dan 29.108 jiwa perempuan. ${ }^{10}$ Dengan 52.388 jiwa penduduk asli dan 5.273 jiwa penduduk pendatang.

Di Kecamatan Klungkung terdapat 5 agama yang dianut oleh masyarakatnya. Kelima agama tersebut adalah Hindu (47.966 jiwa) yang merupakan agama mayoritas, kemudian agama Islam (3.805), disusul agama Budha (1.010), Kristen Protestan (306), dan yang terakhir Kristen Katolik (152). ${ }^{11}$ Penganut agama Islam terbanyak ada di Kelurahan Semarapura Kangin.

Sebelum penulis paparkan mengenai pungutan dana krama tamiu, ada baiknya bila penulis lebih dulu menjelaskan tentang beberapa Kkrama yang ada di Bali, khususnya di Kecamatan

${ }^{10}$ Dinas Tenaga Kerja Kependudukan dan Catatan Sipil Kabupaten Klungkung,_Laporan Penduduk Kecamatan Klungkung Bulan April 2009.

" Departemen Agama Kecamatan Klungkung, data terakhir tahun 2007.

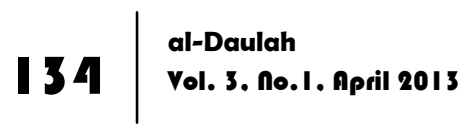


Klungkung. Berdasarkan hasil wawancara yang penulis lakukan dengan beberapa tokoh Banjar adat, dapat penulis uraikan ada tiga jenis krama di Bali khususnya di Kecamatan Klungkung yaitu :

1. Krama Banjar

Krama Banjar adalah penduduk beragama Hindu dan mipil atau tercatat sebagai anggota Desa Pakraman/Banjar adat. Dengan kata lain, mereka yang beragama Hindu dan tinggal di wilayah Banjar adat/desa Pakraman bisa dikatakan sebagai Krama Banjar.

Adapun Kewajiban Krama Banjar adalah : ${ }^{12}$

a. Setiap krama Banjar wajib mentaati semua aturan yang disepakati sebagaimana yang tertuang dalam awig-awig dan simakrama

b. Setiap anggota Banjar wajib menjaga nama baik Banjarnya dan saling membantu sesama anggota Banjar dengan bergotong royong.

c. Setiap krama Banjar diwajibkan untuk ikut terlibat dalam setiap kegiatan baik upacara adat maupun persembahyangan di Pura dengan pembagian pengeluaran (kenan-kenan) yang adil dan dilaksanakan secara bergiliran.

d. Setiap krama Banjar yang absen dalam suatu kegiatan akan dikenakan dose (denda) berupa materi ataupun uang yang besarnya sesuai dengan kesepakatan yang diiambil pada saat sangkepan

Sedangkan Hak Krama Banjar adalah :

a. Setiap krama Banjar berhak menempati tanah desa yang biasanya terletak dalam satu kesatuan dengan krama Banjar yang lain.

b. Setiap krama Banjar berhak dikremasi di setra (kuburan) setempat yang menjadi milik Banjar.

c. Setiap krama Banjar berhak untuk mengeluarkan suara dalam setiap sangkepan Banjar.

d. Setiap krama Banjar berhak mendapatkan bantuan dari krama 
yang lain dalam setiap kegiatan upacara seperti menikah, potong gigi maupun ngaben.

Dengan mengacu pada hak dan kewajiban di atas, ada dua sistem yang dipakai dalam menentukan keanggotaan sebuah Banjar yaitu:

\section{Sistem Karang Ayahan}

Sistem ini mendasarkan pada aturan bahwa tanah yang merupakan wilayah desa Pakraman dimana krama Banjar itu berada adalah berstatus tanah desa atau karang desa. Sehingga semua krama yang menempati tanah ayahan desa diwajibkan untuk menjadi krama Banjar adat dan dikenakan wajib ayahan dan wajib materi. ${ }^{13}$

Wajib materi ini biasanya dipikul oleh seorang kepala keluarga yang disebut dengan ayahan ngarep, jadi andaikan dalam sepetak tanah ayahan desa ada beberapa keluarga maka yang menjadi krama ngarep adalah kepala keluarga yang paling tua dalam susunan sebuah keluarga sedangkan keluarga yang lain disebut dengan roban.

2. Sistem Mapakuren.

Sistem ini tidak didasarkan pada aturan menempati tanah ayahan desa, melainkan didasarkan atas orang yang sudah berkeluarga. Menurut sistem ini seorang pria yang sudah beristri diwajibkan untuk menjadi anggota Banjar.

Semua krama Banjar, baik dalam sistem 1 maupun sistem 2 dikenakan wajib ayahan dan papeson (wajib materi) kecuali para janda, orang yang belum berkeluarga dan sulinggih (wiku) tidak dikenakan ayahan desa ataupun papeson karena dalam kehidupan masyarakat

${ }^{13}$ Dewa Gde Adnyana, selaku Guru Agama Hindu (Pemangku adat) di Banjar Bendul, Kelurahan Semarapura Tengah, Wawancara, Bali, 12 Maret 2009. 
Bali sulinggih dipandang sebagai orang suci dan patut dihormati.

\section{Krama Patedunan.}

Krama patedunan adalah krama atau warga banjar yang diturunkan (patedunan=diturunkan), maksudnya adalah diturunkan dari sebuah keluarga untuk menjadi warga atau krama baru di suatu Banjar. Misalnya, seorang keluarga dari sebuah Banjar yang memiliki anak perempuan, lalu menikah dengan seorang laki-laki dari banjar lain, maka anak perempuan tersebut akan ikut suaminya dan tinggal di Banjar suaminya. Maka perempuan tersebut dikatakan sebagai krama patedunan di Banjar suaminya. ${ }^{14}$

Menurut Ibu Luh Sri Astuti, krama patedunan tidak sama haknya dengan krama Banjar. Mereka tidak mendapatkan hak tanah pakuburan sebagaimana layaknya krama Banjar mendapatkannya. Namun ada hal yang hampir sama dilakukan keduanya, baik krama patedunan maupun krama Banjar akan dikenai pungutan dana punia. ${ }^{15}$

Selain Dana Punia, Krama Patedunan juga dikenai pungutan dana Patedunan Krama yang besarnya sesuai dengan awig-awig banjar adat/desa pakraman. ${ }^{16}$

3. Krama Tamiu. ${ }^{17}$

Penduduk pendatang yang lebih dikenal dengan sebutan tamiu atau krama tamiu merupakan penduduk yang datang dari luar Propinsi Bali untuk tinggal menetap atau tinggal sementara

${ }^{14}$ Luh Sri Astuti, selaku Krama Patedunan di Banjar Besang Kangin, Wawancara, Bali, I I Maret 2009.

${ }^{15}$ Dana Punia adalah iuran sukarela yang dikeluarkan swaktu-waktu oleh krama banjar maupun krama patedunan saat ada upacara adat atau upacara keagamaan seperti saraswati, pagerwesi, ga/ungan, kuningan, odalan, purnama, dll yang dilaksanakan oleh banjar adat/desa pakraman. Besarnya pungutan Dana Punia sesuai ketentuan awig-awig banjar adat/desa pakraman setempat.

${ }^{16}$ Ketut Sudana, selaku Kelian Banjar Banjar Lebah Kelurahan Semarapura Klod, Wawancara, Bali, 2I Maret 2009.

17 Keputusan Pesamuan (rapat) Majelis Desa Pakraman Provinsi Bali Nomor 050/KEP/PSMI/MDP BALI/III/2006 tanggal 3 maret 2006. 
di Propinsi Bali (pasal 1 ayat a Kesepakan Bersama Gubernur Bali dengan Walikota/Bupati se-Bali No.153 tahun 2003).

Sedangkan menurut Ida Bagus Gede Wiyana, Ketua Umum Forum Kerukunan Umat Beragama Propinsi Bali menjelaskan bahwa untuk memberikan pengertian tentang penduduk pendatang, maka ada dua paradigma yang digunakan yaitu: Pertama, Paradigma lama yang mengartikan bahwa Penduduk Pendatang adalah tamu bagi pihak tertentu yang keberadaannya wajib dilaporkan kepada aparat desa dinas dan Desa Pakraman setempat.

Kedua, Paradigma baru yang memaknai Penduduk Pendatang adalah tamu bagi Desa/Banjar Dinas dan Banjar Adat/Desa Pakraman yang keberadaannya diketahui dan dikelola oleh Desa/Banjar Dinas dan Banjar Adat/Desa Pakraman yang bersangkutan dengan menitipkannya pada penduduk setempat yang memiliki fasilitas untuk itu. ${ }^{18}$

Sedangkan dalam Surat Gubernur Bali Nomor 470/7587/B. Tapen tanggal 14 Nopember 2002 lebih ditegaskan lagi dengan menyatakan bahwa "Penduduk pendatang adalah penduduk yang datang akibat mutasi kepindahan antar Kabupaten/Kota atau Propinsi Bali". Dalam Surat Gubernur yang tersebut terakhir ini, penduduk pendatang diklasifikasikan menjadi dua, yaitu:

1. Pendatang menetap, yaitu pendatang dengan lama tinggal minimal tiga tahun.

2. Pendatang tinggal sementara, yaitu pendatang dengan lama tinggal paling lama satu tahun.

Setiap penduduk pendatang akan dikenai biaya administrasi sebesar Rp. 50.000,- untuk Kartu Identitas Penduduk Sementara (KIPS) dan Rp. 5.000,- bagi Surat Tanda Pendaftaran Penduduk Tinggal Sementara (STPPTS) sesuai

18 Imam Ghozali Said, Laporan Kegiatan Lokakarya Penyusunan Pola Pemeliharaan Kerukunan Umat Beragama Melalui Peran FKUB, (Bogor, 2009), 97. 
dengan pasal 4 ayat (a) dan (b) dalam kesepakan bersama tersebut.

Dengan mengacu pada kesepakatan bersama Gubernur Bali dengan Bupati/Walikota se-Bali No. 153 Tahun 2003 dan instruksi Bupati Klungkung Nomor 268 Tahun 2003 tentang pemberlakuan kesepakatan bersama tersebut, maka dibuatlah petunjuk teknis pelaksanaan pendaftaran penduduk pendatang yang dihasilkan pada rapat kerja Kependudukan Tingkat Kabupaten Klungkung tanggal 1 Juli 2004.

Dalam petunjuk teknis tentang pendaftaran penduduk pendatang di Kabupaten Klungkung tersebut diterangkan tentang kewajiban dan hak setiap penduduk pendatang. Salah satu dari kewajibannya selain membayar biaya administrasi sesuai dengan kesepakatan bersama Gubernur Bali dengan Bupati/Walikota se-Bali No.153 Tahun 2003, penduduk pendatang juga di pungut dana krama tamiu oleh Pakraman/Banjar/Desa Adat yang besarnya sesuai dengan awigawig Banjar/Desa Adat/Pakraman setempat. ${ }^{19}$

\section{Penerapan Pungutan Dana krama tamiu}

Dana krama tamiu pertama kali diberlakukan pada tahun 2004 berdasarkan petunjuk teknis pelaksanaan pendaftaran penduduk pendatang yang dihasilkan pada rapat kerja Kependudukan Tingkat Kabupaten Klungkung tanggal 1 Juli 2004. Hal ini berawal dari adanya serbuan penduduk pendatang ke Bali yang semakin meningkat, ruang gerak penduduk masyarakat Bali yang semakin menyempit, serta ditambah dengan adanya tragedi bom Bali I dan II, membuat penerapan dana krama tamiu ini semakin lancar walau ada beberapa hambatan kecil atau penolakan dari warga pendatang (tamiu). Namun pungutan pun tetap diberlakukan setelah kewenangan penuh pengaturan penduduk pendatang diserahkan pada Banjar Adat/Desa Pakraman.

${ }^{19}$ Dinas Tenaga Kerja, Kependudukan, dan Catatan Sipil Kabupaten Klungkung, Petunjuk Teknis Tentang Pelaksanaan Pendaftaran Penduduk Pendatang Di Kabupaten Klungkung, 3.

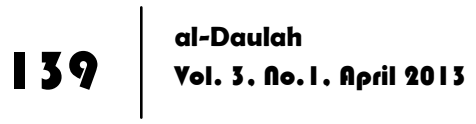


Banjar Adat/Desa Pakraman kemudian membuat aturan sendiri tentang besarnya pungutan dana krama tamiu tersebut. Yang selanjutnya dituangkan dalam pararem atau awig-awig Banjar Adat/Desa Pakraman. Besarnya pungutan tersebut berbeda antara banjar yang satu dengan banjar lainya sesuai dengan hasil sangkepan (rapat) krama banjar. ${ }^{20}$

Penarikan pungutan dana krama tamiu tersebut dilakukan setiap satu bulan sekali yang biasanya dilakukan pada awal bulan minggu pertama. Apabila pada bulan sebelumnya belum membayar, maka penarikannya dilakukan pada bulan berikutnya dengan membayar ganda. ${ }^{21}$

Menurut pengakuan Bapak M. Djunih, besarnya pungutan iuran wajib22 di Banjar Sengguhan awalnya adalah sebesar Rp. 5.000,- perbulan/kk. Namun pada tahun 2009 ini sudah mulai naik kembali sebesar Rp. 10.000,- perbulan/kk. Kenaikan tersebut tanpa adanya musyawarah yang melibatkan penduduk pendatang, melainkan hanya kebijakan dari krama banjar sendiri. ${ }^{23}$

Hal senada juga diakui oleh Bapak Ahamad Syarif, bahwa di banjar tempatnya tinggal juga diberlakukan hal yang sama yaitu dikenai pungutan dana krama tamiu atau iuran wajib sebesar Rp. 5.000,- perbulan /kk. ${ }^{24}$ Bahkan penarikan dana krama tamiu tersebut mencakup seluruh Bali, hanya saja besarnya pungutan ditentukan oleh kebijakan masing-masing Banjar Adat yang tertuang dalam Awig-Awig/Pararem Banjar Adat/Desa Pakraman.

${ }^{20}$ Ketut Sudana, Kelian Banjar Banjar Lebah Kelurahan Semarapura Klod, Wawancara, Bali, 21 Maret 2009.

$21 \mathrm{H}$. Matnari, Penduduk pendatang di Banjar Sengguhan Kelurahan Semarapura Kangin, Wawancara, Bali, 14 Maret 2009.

22 luran wajib lebih dikenal oleh warga penduduk pendatanag karena memang yang diinformasikan kepada mereka adalah membayar iuran wajib, sedangkan dana krama tamiu merupakan bahasa yang tertuang dalam peraturannya yaitu dalam petunjuk teknis tentang pendaftaran penduduk pendatang. Namun secara esensial kedua bahasa tersebut memiliki makna yang sama.

23 M. Djunih, Penduduk pendatang di Banjar Sengguhan Kelurahan Semarapura Kangin, Wawancara, Bali, 13 Maret 2009.

${ }^{24}$ Ahmad Syarif, Penduduk pendatang di Banjar Gunung Niang Kelurahan Semarapura Klod Kangin, Wawancara, 27 Maret 2009. 
Seperti penuturan Bu Hafid, menurutnya di Kabupaten Klungkung masih tergolong ringan pungutan dana krama tamiu tersebut dibandingkan dengan di banjar tempatnya tinggal. Diakui bahwa dirinya di Kabupaten Gianyar dikenai pungutan iuran wajib (dana krama tamiu) tersebut sebesar Rp. 25.000/orang setiap bulannya. ${ }^{25}$

Menurut keterangan Bpk H. Saniman, pungutan dana krama tamiu merupakan iuran yang ditarik dari warga pendatang yang tinggal di suatu banjar dan tidak menjadi anggota banjar. Jadi menurut beliau, semua warga pendatang yang telah masuk dalam angota banjar dan menjadi krama banjar maka sudah tidak lagi dikenai pungutan dana krama tamiu. ${ }^{26}$

Setiap penduduk pendatang terutama yang mayoritas dari mereka adalah beragama Islam tidaklah mungkin akan menjadi anggota banjar walaupun mereka tinggal di banjar tersebut. ${ }^{27}$ Karena apabila mereka menjadi anggota banjar, maka secara tidak langsung mereka harus masuk dalam agama mereka (Hindu) sebab, setiap krama banjar diwajibkan untuk ikut terlibat dalam setiap kegiatan baik upacara adat maupun persembahyangan di pura dengan pembagian pengeluaran (kenan-kenan) yang adil dan dilaksanakan secara bergiliran. Selain itu, krama banjar pada dasarnya mempunyai hak dan kewajiban terhadap parhyangan, ${ }^{28}$ pawongan $^{29}$ dan palemahan ${ }^{30}$ yang salah satu dari ketiganya tidak

${ }^{25}$ Ibu Hafid, penduduk pendatang di Kawasan Pasar Senggol Gianyar, Wawancara, Bali, 29 Maret 2009.

${ }^{26}$ H. Saniman, Pegawai Negeri Sipil di Dinas Tenaga Kerja Kependudukan dan Catatan Sipil Kabupaten Klungkung yang sekaligus Ketua Takmir Masjid Agung Al-Fatah Kampung Jawa Klungkung, Wawancara, Bali, 01 April 2009.

$27 \mathrm{H}$. Alfian, Tokoh Masyarakat Islam di Kecamatan Klungkung yang sekaligus sebagai Kepala Sekolah SLTP Hasannudin Klungkung-Bali, Wawancara, Bali, 03 April 2009.

${ }^{28}$ Parhyangan adalah hubungan antara krama dengan Ida Sang Hyang Widhi. Parhyangan Desa terdiri dari Pura Puseh, Pura Desa / Bale Agung, Pura Dalem disebut Kahyangan Tiga dan atau Pura yang disungsung berkait dengan eksistensi Kahyangan Tiga dalam wilayah Desa Pakraman.

29 Pawongan adalah segala urusan mengenai krama desa, hubungan antara krama, dan antara krama dengan Desa Pakraman/BanjarAdat.

30 Palemahan adalah segala urusan mengenai tanah, bangunan selain parhyangan, lingkungan atau wilayah Banjar Adat/Desa Pakraman, dan hubungan antara krama dengan tanah, dengan bangunan selain parhyangan, dengan lingkungan atau wilayah BanjarAdat/Desa Pakraman.

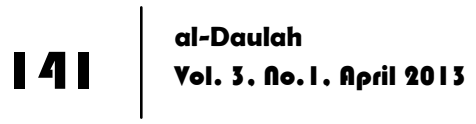


mungkin dilaksanakan oleh mereka yang beragama Islam. Untuk itulah tidak mungkin mereka yang beragama Islam menjadi anggota banjar melainkan mereka akan tetap menjadi krama tamiu di suatu banjar tersebut.

Namun, di Kecamatan Klungkung ini ada juga penduduk pendatang yang tidak dikenai pungutan dana krama tamiu, yaitu penduduk pendatang yang tinggal di Desa Kampung Gelgel. ${ }^{31}$ Semua warganya di Desa Kampung Gelgel ini adalah beragama Islam yang mencapai 952 jiwa. ${ }^{32}$ Akan tetapi, walau tidak dipungut dana krama tamiu, setiap penduduk pendatang tetap dikenai biaya KIPS (Kartu Identitas Penduduk Sementara) dan STPPTS (Surat Tanda Pendaftaran Penduduk Tinggal Sementara) sesuai dengan ketentuan yang berlaku berdasarkan Kesepakatan Bersama Gubernur Bali dengan Bupati/Walikota se-Bali No. 153 Tahun 2003.

Tidak ada perjanjian khusus yang dilakukan antara penduduk pendatang dengan Banjar Adat/Desa Pakraman, apabila mereka hendak tinggal di wilayah Banjar Adat/Desa Pakraman. Namun ada beberapa persyaratan yang harus dipenuhi oleh penduduk pendatang agar mereka bisa tinggal di lingkungan Banjar Adat/Desa Pakraman tersebut. Adapun syarat-syarat pendaftaran penduduk ${ }^{33}$ pendatang sebagai berikut ${ }^{34}$ :

${ }^{31}$ H. Safwin, Tokoh Agama Islam di Kampung Lebah Klungkung, Wawancara, Bali, 31 Maret 2009.

32 M Nur llahi, Sekretaris Desa Kampung Gelgel, Wawancara, Bali, 24 Maret 2009.

33 Pendaftaran Penduduk adalah pencatatan biodata penduduk, pencatatan atas pelaporan peristiwa kependudukan dan pendataan penduduk rentan administrasi kependudukan serta penerbitan dokumen penduduk berupa identitas, kartu atau surat keterangan kependudukan.

${ }^{34}$ Sesuai dengan aturan yang tertuang dalam Petunjuk teknis tentang pelaksanaan pendaftaran penduduk pendatang di Kabupaten Klungkung, oleh Dinas Tenaga Kerja, Kependudukan, dan Catatan Sipil Kabupaten Klungkung, h. 3 - 17 
A. Penduduk Pendatang Tinggal Sementara ${ }^{35}$

1. Memiliki Kartu Tanda Penduduk (KTP) asli dari daerah asal.

2. Membawa surat keterangan bepergian dari kepala desa daerah asal.

3. Surat Keterangan Catatan kepolisian dari POLRI daerah asal.

4. Memiliki Penjamin ${ }^{36}$ yang dinyatakan dengan surat pernyataan sebagai penjamin.

5. Surat pengantar dari Kepala Dusun/Lingungan dengan Rekomendasi dari Kelian Banjar/Bendesa Adat/Pakraman di daerah tujuan.

6. Fotokopi Akta Kelahiran.

7. Membayar biaya administrasi dalam rangka peneribitan KIPS sesuai dengan Kesepakan Bersama Gubernur Bali dengan Walikota/Bupati se-Bali No. 153 Tahun 2003.

B. Penduduk Pendatang Tinggal Menetap ${ }^{37}$

1. Penduduk Pendatang Tinggal Menetap WNI

a. Surat keterangan pindah dari Bupati/Walikota atau Pejabat yang ditunjuk di daerah asal.

b. Surat Keterangan Catatan kepolisian dari POLRI daerah asal.

c. Surat keterangan bekerja dari pemberi kerja atau surat keterangan memiliki usaha sendiri dari Kelian

35 Penduduk Pendatang Tinggal Sementara adalah warga negara Indonesia yang tinggal di luar domisili asli atau tempat tinggal tetapnya dengan Kartu Identitas Penduduk Sementara (KIPS) atau Surat Tanda Pendaftaran Penduduk Tinggal Sementara (STPPTS). (Pasal I b Kesepakan Gubernur Bali dengan Walikota/Bupati se-Bali No. I 53 Tahun 2003)

${ }^{36}$ Penjamin adalah orang atau badan hukum yang menjamin keberadaan penduduk pendatang tinggal sementara. Adapun syarat dari penjamin adalah, Pertama, Penduduk tetap desa/kelurahan di mana penduduk pendatang yang bersangkutan didaftarkan dengan bukti KTP yang masih berlaku. Kedua, memahami dan mematuhi ketentuan administrasi kependudukan.

${ }^{37}$ Penduduk Pendatang Tinggal Menetap adalah pendatang yang telah memiliki pekerjaan tetap dan mempunyai tenpat tinggal tetap. Dan termasuk dalam Penduduk Pendatang Tinggal Menetap adalah mutasi/perpindahan TNI/POLRI, PNS, Mahasiswa dan Pelajar. 
Banjar/Bendesa Adat/Pakraman yang diketahui oleh kepala desa/kelurahan.

d. Surat pengantar dari Kepala Dusun/Lingungan dengan Rekomendasi dari Kelian Banjar/Bendesa Adat/Pakraman di daerah tujuan.

e. Fotokopi Akta Kelahiran.

f. Surat keterangan bertempat tinggal tetap yang disertai bukti-bukti hak milik atau hak pakai yang sah dengan lama pemilikan atau pemakaian minimal tiga (3) tahun.

g. Membayar biaya administrasi sesuai dengan peraturan desa atau keputusan Kepala Kelurahan setempat.

2. Penduduk Pendatang yang berstatus TNI/POLRI, PNS, dan Karyawan BUMN/BUMD serta Pelajar atau Mahasiswa.

a. Surat keterangan pindah dari Bupati/Walikota atau Pejabat yang ditunjuk di daerah asal.

b. Fotokopi kartu pegawai (bagi PNS dan karyawan BUMN/BUMD) dan Kartu Anggota bagi TNI/POLRI serta Kartu Pelajar atau Mahasiswa bagi Pelajar dan Mahasiswa

c. Surat pengantar dari Kepala Dusun/Lingungan di daerah tujuan untuk memohon Surat Keterangan Lapor Diri (SKLD) dengan Rekomendasi dari Kelian Banjar/Bendesa Adat/Pakraman.

d. Fotokopi Akta Kelahiran dan Kartu Keluarga

e. Membayar biaya administrasi sesuai dengan peraturan desa atau keputusan Kepala Kelurahan setempat.

Apabila penduduk pendatang baik tinggal sementara maupun tinggal menetap itu adalah Warga Negara Asing, maka persyaratannya sebagai berikut:

1. Surat keterangan pindah dari Bupati/Walikota/Pejabat yang ditunjuk dari daerah asal

2. Surat keterangan pendaftaran penduduk WNA tinggal terbatas dari Bupati/Pejabat yang ditunjuk.

3. Dokumen Keimigrasian (KITAS) 
4. Surat pengantar dari Kepala Dusun/Lingkungan dengan rekomendasi dari Kelian Banjar/Desa Pakraman daerah tujuan.

5. Pajak bangsa asing dan membayar biaya administrasi sesuai ketentuan.

Secara prosedural, Setelah beberapa kelengkapan administrasi terpenuhi, penduduk pendatang bersama penjaminnya selambatlambatnya 2X24 jam harus melapor langsung pada Kelian Banjar/Bendesa Adat/Pakraman untuk mohon surat rekomendasi. ${ }^{38}$ Kelian Banjar/Bendesa Adat/Pakraman akan menerbitkan surat rekomendasi tersebut serta memungut dana krama tamiu yang sesuai dengan ketentuan Awig-Awig/Pararem Banjar/Desa Pakraman. Yang selanjutnya pungutan dana krama tamiu tersebut akan ditarik setiap bulan oleh petugas keamanan Banjar Adat/Desa Pakraman yaitu Pecalang. Selain menerbitkan surat rekomendasi dan memungut dana krama tamiu, Kelian Banjar/Bendesa Adat/Pakraman juga akan memberikan penjelasan mengenai swadharmaning krama tamiu ${ }^{39}$ di Banjar/Desa Pakraman..$^{40}$

Setelah mendapatkan surat rekomendasi dari Kelian Banjar/Bendesa Adat/Pakraman, maka penduduk pendatang bersama penjaminnya harus segera melaporkan kedatangannya secara langsung kepada Kepala Dusun/Lingkungan. Kemudian membayar biaya administrasi untuk penerbitan KIPS/STPPTS sesuai dengan ketentuan yang berlaku. ${ }^{41}$

Selain membayar biaya administrasi untuk KIPS/STPPTS dan pungutan dana krama tamiu, ada beberapa kewajiban yang juga harus dilakukan oleh penduduk pendatang selaku krama tamiu, yaitu menghormati aturan yang menyangkut sukerta tata

${ }^{38} \mathrm{H}$. Sujamin, Penduduk pendatang yang sudah tinggal menetap di Banjar Mergan dan menjadi penjamin bagi dua pekerjanya yaitu Budi dan Burhan yang tinggal di Banjar yang sama, Wawancara, Bali, 29 Maret 2009.

39 Swadharmaning Krama Tamiu adalah aturan atau tata cara berperilaku bagi seorang tamu yang di dalamnya menyangkut hak dan kewajiban sebagai tamu.

40 Wayan Mardika, selaku Kelian Banjar Banjar Gunung Niang, Kelurahan Semarapura Klod Kangin, Wawancara, Bali, 17 Maret 2009.

${ }^{41}$ I Made Asta Sudarsana, selaku Kepala Desa Tojan, Wawancara, Bali, 30 Maret 2009.

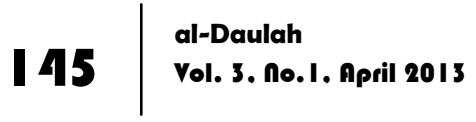


parhyangan, pawongan, dan palemahan yang berlaku di Banjar/Desa Adat/Pakraman setempat, serta melaksanakan swadharmaning krama tamiu yang diatur dalam awig-awig atau pararem Banjar/Desa Adat/Pakraman setempat. ${ }^{42}$

\section{Implikasi dari Pungutan Dana Krama Tamiu}

Ketika seseorang menjalankan kewajibannya, maka ada hak pada dirinya untuk mendapatkan atau menerima sesuatu atas kewajiban yang telah dilakukannya. Untuk itulah, sebagai bentuk konsekuensi atau implikasi dari biaya administrasi dan pungutan Dana krama tamiu tersebut, maka secara administratif setiap penduduk pendatang mendapatkan beberapa hak yang terjamin, diantaranya:

a. Setiap penduduk pendatang tinggal sementara diberikan dokumen kependudukan berupa:

1. Surat Keterangan Tinggal Sementara (SKTS) untuk WNI

2. Surat Keterangan Tempat Tinggal (SKTT) untuk WNA

b. Setiap penduduk pendatang tinggal menetap diberikan dokumen kependudukan berupa:

1. Kartu Keluarga (KK)

2. Kartu Tanda Penduduk (KTP)

Sedangkan dari beberapa hasil wawancara penulis dengan beberapa narasumber, maka dapat penulis simpulkan bahwa ada beberapa jaminan hak lain yang bisa juga didapatkan oleh penduduk pendatang, yaitu:

1. Pengayoman dari segala macam bahaya (pasayuban sakala, pasayuban kapancabayan), seperti pertolongan bila terjadi musibah, seperti hanyut karena banjir, kebakaran, pencurian, penganiayaan, dan lain-lain. ${ }^{43}$

2. Pengawasan dan Perlindungan Keamanan. ${ }^{44}$

42 I Wayan Widana, selaku Kepala Dusun Tojan Klod, Desa Tojan, Wawancara, Bali, 30 Maret 2009.

43 Wayan Sutapa, Kepala Lingkungan Banjar Sengguhan, Kelurahan Semarapura Kangin, Wawancara, Bali, 16 Maret 2009.

${ }^{44}$ Made Pastika, Kelian Banjar Banjar Gunung Niang, Kelurahan Semarapura Klod Kangin, 
Pengawasan dan perlindungan keamanan ini dilakukan oleh petugas keamanan banjar adat yaitu pecalang atau langlang. Pecalang atau Langlang mempunyai tugas dan wewenang untuk menjaga keamanan dan ketertiban wilayah, baik ditingkat banjar dan atau di wilayah Desa Pakraman. Pacalang melaksanakan tugas-tugas pengamanan dalam wilayah Desa Pakraman dalam hubungan pelaksanaan tugas agama dan adat serta acara-acara penting lainnya apabila dimohon oleh instansi/lembaga resmi dan sesuai pararem Desa Pakraman. Pacalang diangkat/dipilih dan diberhentikan oleh Desa Pakraman/Banjar Adat berdasarkan paruman desa serta persyaratan dan sesana maupun busana diatur di dalam awigawig/pararem Desa Pakraman.

Pengawasan dan perlindungan keamanan yang diberikan banjar terhadap penduduk pendatang meliputi banyak hal, baik keamanan diri maupun keamanan ritual keagamaan yang dijalaninya. Seperti perlindungan saat menjalankan upacara keagamaan dll. ${ }^{45}$

Namun demikian, pengawasan dan perlindungan keamanan ini tidak serta merta dapat dirasakan oleh penduduk pendatang. Karena masih adanya kecemasan penduduk pendatang terhadap gangguan dari kalangan tertentu yang sering melakukan mabuk-mabukan di lingkungan sekitar Banjar Adat. Hal ini memang agak sulit diatasi karena mabuk-mabukan dengan minum tuaklarak seolah sudah menjadi tradisi bagi masyarakat Klungkung khususnya dan Bali pada umumnya. Sehingga tidak mudah untuk menghilangkan kebiasaan tersebut. Bahkan banyak kejadian yang melibatkan petugas keamanan banjar sendiri (pecalang) ikut terlibat dalam aksi mabuk-mabukan tersebut. Pemerintah Banjar Adat/Desa Pakraman sendiri masih lemah dalam menangani para oknum 
yang suka mabuk-mabukan ini. Walaupun pernah ada beberapa tindakan tegas yang diambil oleh krama banjar terhadap mereka, misalnya dengan melarang mereka mabuk-mabukan di pinggir jalan atau trotoar. Namun, peringatan dan larangan tersebut tidak pernah diindahkan oleh mereka. Hal ini terjadi disebabkan karena tidak adanya sanksi tegas yang diberikan kepada mereka. Sehingga keberadaan mereka tetap saja menjadi sedikit kekhawatiran bagi penduduk pendatang.

3. Berhak Mendapatkan Pelayanan Kesehatan Dan Pengobatan Gratis.

Bagi warga yang sudah tinggal di wilayah Banjar Adat dan sudah menjalankan kewajibannya, maka mereka berhak juga mendapatkan pengobatan gratis dari Posyandu yang ada di lingkungan Banjar tersebut.

4. Berhak menggunakan fasilitas Banjar Adat/Desa Pakraman. ${ }^{46}$

Apabila krama tamiu memiliki hajatan atau mengadakan kegiatan keagamaan, maka diperbolehkan menggunakan fasilitas yang dimiliki Banjar Adat, seperti menggunakan Palemahan Banjar dll. Namun pada realitasnya banyak penduduk pendatang yang tidak memanfaatkan fasilitas tersebut karena apabila memiliki hajatan lebih menggunaan fasilitas yang dimiliki masjid daripada yang disediakan oleh Banjar Adat.

Selain dari beberapa hak tersebut, menurut keterangan Bapak Wayan bahwa hasil dari pungutan dana krama tamiu tersebut sebagian juga digunkan untuk membayar petugas kebersihan yang diangkat oleh Banjar Adat. Memang petugas kebersihan dari Dinas Kebersihan dan Lingkungan Hidup kabupatem disediakan, namun petugas itu saja masih dianggap belum cukup untuk membersihkan sampah warga secara keseluruhan. Sehingga di setiap Banjar Adat tetap diangkat petugas kebersihan tersendiri yang akan mengambil sampah-

${ }^{46} \mathrm{H}$. Alfian, Tokoh Masyarakat Islam di Kecamatan Klungkung yang sekaligus sebagai Kepala Sekolah SLTP Hasannudin Klungkung- Bali, Wawancara, Bali, 03 April 2009.

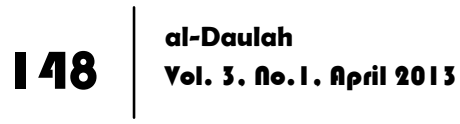


sampah krama dari setiap gang/lorong jalan di yang ada di banjar tersebut. ${ }^{47}$ Petugas tersebut diangkat dan diberhentikan oleh Banjar Adat/Desa Pakraman, sehingga upah yang diterimapun diambilakan dari kas Banjar Adat yang salah satunya juga diambil dari hasil pungutan dana krama tamiu yang masuk ke banjar tersebut.

Hasil dari pungutan dana krama tamiu tersebut juga digunakan untuk membayar pecalang, untuk upacara adat, perbaikan pura serta untuk kepentingan Banjar Adat/Desa Pakraman dalam menjalankan tugasnya sebagai bagian dari pemerintahan adat di Kec. Klungkung Kab. Klungkung khususnya dan Bali pada umumnya. ${ }^{48}$

Penerapan Pungutan Dana Krama Tamiu bagi Penduduk Pendatang di Kec. Klungkung Kab. Klungkung-Bali Perspektif Fiqh Siyasah

Penduduk pendatang di Kecamatan Klungkung yang mayoritas beragama Islam termasuk golongan minoritas yang hidup dalam mayoritas umat Hindu. Sebagai kelompok minoritas, penduduk pendatang selayaknya juga memiliki hak yang sama sebagaimana penduduk asli diperlakukan. Sebagaimana Islam pernah menerapkan jizyah ${ }^{49}$ (pajak kepala) terhadap ahl al-zimmah dan memberlakukan mereka setara dengan umat Islam. ${ }^{50}$ Mendapatkan hak, jaminan sosial dan keamanan, serta perlindungan yang sama sebagaimana Islam memberikan perlindungan terhadap umatnya. Sehingga prinsip keadilan tidak

47 Wayan, Krama Banjar Sengguhan, Kelurahan Semarapura Kangin, Wawancara, Bali, 18 Maret 2009.

48 Komang Sumantri, Pecalang Banjar Bendul, Kelurahan Semarapura Tengah, Wawancara, Bali, 04 April 2009.

49 Jizyah adalah pajak kepala atau perorangan yang dikenakan terhadap orang-orang non-muslim tertentu yang telah mengikat perjanjian dengan pemerintah. Lihat Departemen Agama, Ensiklopedi Islam di Indonesia, jilid II, (Jakarta: CV Anda Utama, I993), 526.

50 Abd al-Wahab Khalaf, Politik Hukum Islam, (Yogyakarta: PT. Tiara Wacana Yogya, 1994), 94. 
terbatas pada kaum muslimin saja, melainkan mencakup semua warga negara sekalipun tidak beragama Islam. ${ }^{51}$

Bila melihat dari kacamata Islam, dengan jumlah penduduk pendatang sebanyak 5.273 jiwa dan 3.805 jiwa diantaranya adalah yang beragama Islam. Maka keberadaan penduduk pendatang bisa digolongan sebagai kelompok minoritas yang juga seharusnya mendapatkan hal yang setara dengan penduduk asli yang tinggal di Kecamatan Klungkung. Sebab, golongan minoritas dalam Islam sangat dimuliakan. Karena Islam memberlakukan konsep keadilan terhadap semua kalangan, begitu juga terhadap kaum minoritas.

Agar kaum mayoritas tidak melakukan tindakan kezaliman dan penindasan terhadap kaum minoritas, maka Islam menancapkan patokan perlindungan terhadap kaum minoritas. Islam mengangkat kaum minoritas ke posisi yang setara dengan kaum mayoritas. Dalam Islam, keduanya dianggap sejajar dalam satu ikatan, yakni ikatan perlindungan. Bahkan pada kaum minoritas ini disematkan sifat kesucian, karena mereka di bawah perlindungan Allah dan Rasul-Nya, bukan semata perlindungan dari kaum muslimin saja. ${ }^{2}$

Berangkat dari kondisi riil di Kecamatan Klungkung tentang keberadaan penduduk pendatang yang dikenai pengutan dana krama tamiu. Penulis melihat apa yang dilakukan pemerintah melalui instruksi Banjar Adat/Desa Pakraman terhadap penduduk pendatang dengan memungut dana krama tamiu sama seperti pungutan jizyah terhadap ahl al-zimmah yang sudah pernah diterapkan Islam pada masanya. Karena secara formil apa yang diberlakukan terhadap penduduk pendatang di Kecamatan Klungkung memiliki kesamaan dengan penarikan jizyah terhadap kafir zimmi dalam konsep Islam.

51 Ahmad Zaki, Yamani, Syariat Islam yang Kekal dan Persoalan Masa Kini, (Jakarta Selatan: PT Intermasa, 1977), 77.

52 Muhammad, Jamaluddin Athiya, Fiqh Baru bagi Kaum Minoritas, HAM dan Supremasi Hukum sebagai Keniscayaan, (Bandung: Marja, 2006), 152. 
Dilihat dari penerapan pungutan dana krama tamiu tersebut walau tidak ada unsur agama yang ditonjolkan sebagaimana jizyah yang diberlakukan oleh umat Islam terhadap kafir zimmi. Namun secara implisit penerapan pungutan tersebut bisa dikatakan ada motif agamanya dan mengikuti konsep jizyah dalam Islam karena mayoritas dari penduduk pendatang tersebut adalah beragama Islam, sementara yang memungutnya adalah mereka yang bergama hindu. Apalagi latar belakang dari penerapan aturan tersebut berawal dari tragedi bom Bali yang pelakunya adalah termasuk dari golongan umat Islam sendiri. Inilah yang kemudian oleh masyarakat Hindu Bali dijadikan tameng untuk membatasi dan menekan keberadaan penduduk pendatang. Sehingga pungutan dana krama tamiu tersebut melalui institusi Banjar Adat/Desa Pakraman tetap berjalan ajeg.

\section{Syarat-Syarat Pungutan}

Bila melihat dari syarat-syaratnya, penerapan pungutan dana krama tamiu dan penarikan jizyah secara substansial tidak jauh berbeda.

a. Syarat Mampu secara Ekonomi

Dalam konsep Syiasah Shar'iyyah, penarikan pungutan jizyah diberlakukan hanya kepada mereka yang mampu secara ekonomi. Sementara budak dan hamba sahaya dibebaskan dari pungutan jiayah. Hal ini membuktikan bahwa ada unsur sosial yang dipertimbangkan dalam memberlakukan jizyah terhadap mereka yang meminta perlindungan keamanan dalam Negara Islam. Hal ini berbeda dengan yang terjadi di Kecamatan Klungkung, secara formil pungutan dana krama tamiu tersebut diberlakukan terhadap semua penduduk pendatang tanpa mengenal status sosial maupun ekonomi. Namun demikian, dari pengamatan yang penulis lakukan, hampir semua penduduk pendatang mampu membayar pungutan tersebut, karena mayoritas dari mereka sudah memilki pekerjaan. Walaupun ada sebagian dari mereka yang hidup dibawah taraf 
status sosial masyarakat dan merasa berat dengan besarnya pungutan yang diberlakukan. Hal ini menunjukkan bahwa Banjar Adat/Desa Pakraman sudah melakukan pengawasan yang serius terhadap penduduk pendatang yang masuk di wilayahnya. Sehingga penarikan pungutan dana krama tamiu tersebut tidak lagi mengacu pada syarat mampu secara ekonomi, melainkan hal itu sudah menjadi konsekuensi dari kedatangan mereka di Kecamatan Klungkung.

Dengan demikian, bisa dikatakan bahwa Banjar Adat/Desa Pakraman secara substansial juga mempertimbangkan faktor ekonomi dalam menerima penduduk pendatang. Karena penerimaan mereka berkaitan erat dengan pungutan dana krama tamiu tersebut, maka Banjar Adat/Desa Pakraman akan menolak mereka bahkan tidak menerima kehadirannya apabila mereka tidak memiliki pekerjaan tetap. Dari sinilah dapat dikatakan bahwa faktor mampu secara ekonomi juga menjadi pertimbangan Banjar Adat/Desa Pakraman.

\section{b. Laki-Laki}

Pungutan jizyah hanya dibebankan kepada laki-laki karena memiliki kewajiban untuk berperang. Sedangkan perempuan terbebas dari pungutan jizyah karena perempuan tidak memiliki kewajiban untuk berperang. Hal ini hampir sama dalam penerapan pungutan dana krama tamiu, dimana pungutan tersebut hanya dibebankan kepada kepala keluarga yang bertanggung jawab atas seluruh anggota keluarganya. Jadi, dilihat pada sisi ini hampir tidak ada perbedaan antara jizyah dengan pungutan dana krama tamiu karena pembebanannya sama-sama hanya ditanggung oleh laki-laki atau kepala keluarga. 
c. Mengikat Perjanjian Damai

Dalam penerapan Dana krama tamiu tersebut, penduduk pendatang walau secara formal tidak mengikat perjanjian dengan Banjar Adat/Desa Pakraman (mereka yang beragama hindu), namun secara tidak langsung melalui Banjar Adat/Desa Pkaraman tersebut mereka telah diikat oleh perjanjian ketika mereka bersama penjaminnya melaporkan kedatangannya pada Kelian Banjar/Bendesa Adat/Pakraman untuk mohon surat rekomendasi. Inilah yang menurut penulis sebagai bentuk akad perjanjian antara penduduk pendatang dengan Kelian Banjar/Bendesa Adat/Pakraman walaupun tidak tersurat secara eksplisit bentuk dari perjanjian tersbut.

Dikatakan sebagai bentuk perjanjian karena pada saat pelaporan tersebut, penduduk pendatang sudah mendapatkan penjelasan mengenai hak dan kewajiban mereka dalam Swadharmaning Krama Tamiu oleh Kelian Banjar/Bendesa Adat/Pakraman setempat. Yang lebih lanjut aturan tersebut tertuang dalam awig-awignya. Bahkan saat awal pelaporannya tersebut, mereka sudah dipungut Dana krama tamiu di luar biaya administrasi yang ditentukan untuk penerbitan KIPS/STPPTS.

Hal ini tidak jauh berbeda dengan konsep jizyah dalam pemerintahan Islam. Dalam Islam, tidak semua orang kafir dikenai pungutan jizyah, hanya mereka yang mengikat perjanjian damailah yang dikenai pungutan jizyah. Sedangkan mereka yang tidak mengikat perjanjian $z \backslash$ immah akan terbebas dari pungutan jizyah. Sebagaimana yang pernah dicontohkan oleh Rasululah ketika mengikat perjanjian damai dengan Yohanna bin Ruba, seorang amir (penguasa) Aila yang membayar jizyah sebesar 3000 dinar tiap tahun.

Dengan demikian, penerapan pungutan dana krama tamiu oleh Banjar Adat/Desa Pakraman dan penarikan jizyah oleh pemerintahan Islam secara substansi sama-sama melakukan 
ikatan perjanjian sebelum menerapkan pungutan tersebut, walaupun secara teknis proses perjanjian tersebut berbeda.

\section{d. Merdeka, Sehat Fisik dan Mampu Berperang}

Merdeka, sehat fisik dan mampu berperang menjadi syarat bagi penarikan jizyah sehingga mereka terbebas dari kewajiban berperang dan berhak mendapatkan perlindungan keamanan.

Dalam realitasnya di era modern ini terutama di Kecamatan Klungkung, penulis melihat tidak ada lagi penduduk pendatang yang tidak merdeka. Karena semuanya memiliki kebebasan dan hal itu sudah dijamin oleh negara. Bila sehat fisik dan mampu berperang menjadi syarat bagi penarikan jizyah, hal ini tidak serta merta menjadi syarat bagi pungutan dana krama tamiu. Namun, dilihat dari keberadaan penduduk pendatang di Kecamatan Klungkung, berdasarkan pengamatan penulis umur rata-rata pekerja di sana antara 20-45 tahun, maka hal ini dapat penulis kategorikan mereka masih termasuk memiliki kesehatan fisik dan mampu berperang. Walaupun ada sebagian dari mereka yang sakit dan tidak mampu bekerja, namun secara umum mereka bisa digolongkan memiliki sehat fisik dan mampu berperang.

\section{Bentuk Perjanjian}

Penerapan pungutan dana krama tamiu terhadap penduduk pendatang di Kecamatan Klungkung bahkan di Bali pada umumnya memang tidak jauh berbeda dengan konsep jizyah yang pernah diterapkan Islam, hanya objek dan sabjeknya saja yang berbeda. Dalam sejarah Islam, kelompok minoritas tersebut adalah orang-orang ahl al-kitab, yaitu Yahudi, Nasrani, dan Majusi. Sedangkan dalam kondisi riil yang terjadi di Klungkung justru sebaliknya, kelompok minoritas itu adalah orang Islam sendiri yang merupakan penduduk pendatang di sana. 
Walaupun tanpa adanya paksaaan, setiap penduduk pendatang akan membayar besarnya pungutan dana krama tamiu tersebut, karena itulah pilihan bagi mereka apabila ingin tetap tinggal di wilayah Banjar Adat/Desa Pakraman. Model ini serupa dengan perjanjian zimmah khusus yaitu izin menetap yang diberikan suatu Negara Islam kepada seorang atau beberapa orang non-muslim. Atau dengan kata lain pemberian kewarganegaraan kepada orang asing oleh negara yang dimasukinya dengan maksud untuk menetap selamanya. Dalam pemerintahan Islam mereka yang mengikat perjanjian zimmah khusus tetap diberlakukan jizyah baik ditarik secara individu maupun kelompok oleh penguasa muslim setempat dengan ketentuan dan syarat-syarat yang ditentukan setempat. Begitu juga yang terjadi dengan penduduk pendatang yang menetap di Kecamatan Klungkung, mereka tetap ditarik pungutan dana krama tamiu walaupun sudah tinggal menetap dalam tempo yang lama.

\section{Besarnya Pungutan}

Dalam konsep Siyasah Shar'iyyah, besarnya pungutan jizyah beraneka macam bentuknya sesuai dengan model perjanjian yang dilakukan. Jika jizyah yang dibayar dikarenakan atas dasar perdamaian (Jizyah Sulhiyah), maka kadarnya ditentukan sesuai dengan kesepakatan dalam perjanjian perdamaian tersebut. Jika jizyah yang dibayar dikarenakan penaklukkan dalam perang (Jizyah Gair Sulhiyah), maka kadarnya ditentukan oleh pemerintah Islam. ${ }^{53}$

Melihat dari bentuk perjanjian tersebut, maka apa yang terjadi di Kecamatan Klungkung, antara Banjar Adat/Desa Pakraman dengan penduduk pendatang dapat dikategorikan sebagai jizyah gair sulhiyah, karena besarnya pungutan dana krama tamiu yang dikeluarka oleh penduduk pendatang

${ }^{53}$ Djazuli, Fiqh Siyasah, (Jakarta : Kencana, 2007), 232.

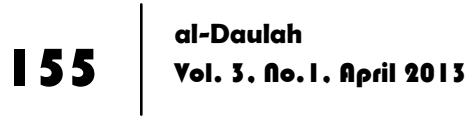


ditentukan oleh Banjar Adat/Desa Pakraman dan bukan dari hasil musyawarah antara krama tamiu (penduduk pendatang) dengan krama banjar.

Sementara besarnya pungutan yang ditarik oleh Banjar Adat/Desa Pakraman terhadap penduduk pendatang berbeda antara banjar yang satu dengan lainnya. Hal ini sesuai dengan hasil sangkepan (rapat) krama banjar dan tertuang dalam awigawig mereka. Di Kecamatan Klungkung, besarnya pungutan dana krama tamiu tersebut adalah antara Rp. 5.000,- hingga Rp. 10.000,- perbulan setiap keluarga. Maka bila setahun, setiap penduduk pendatang harus mengelurkan uang sebesar \pm Rp. 60.000,- hingga Rp. 120.000,- perkeluarga.

Secara jumlah pungutan dana krama tamiu memang berbeda dengan pungutan jizyah. Besarnya pungutan jizyah juga berbeda sesuai dengan jenis perjanjian zimmah dan keputusan pemerintah Islam dalam menetapkan besarnya pungutan jizyah. Namun, ada ketentuan umum yang banyak dijadikan rujukan bagi penerapan jizyah yaitu bagi mereka yang miskin dan tidak mempunyai usaha (adna) adalah sebesar 12 dirham. Sedangkan atas orang-orang yang berada dikelas pertengahan (awsat) dikenakan sebesar 24 dirham dan atas orang-orang kaya ( $\left.a^{\prime} l a\right)$ adalah 48 dirham. ${ }^{54}$ Walaupun beda secara jumlah, namun secara substansi apa yang Banjar Adat/Desa Pakraman terapkan tidak jauh berbeda dengan konsep jizyah, hanya saja dalam jizyah memperhitungkan status sosial atau kemampuan ekonomi warganya sedangkan dalam pungutan dana krama tamiu semua penduduk pendatang disamaratakan besar pungutannya.

Sedangkan pemasukan dari pungutan dana krama tamiu tersebut seluruhnya menjadi kas banjar adat/desa pakraman dan digunakan untuk kepentingan banjar dalam rangka memberikan pelayanan, pengawasan dan kenyamanan

54 Muhammad, al-Allamah, Rahmah al-Ummah fi lkhtilaf al- A'immah, diterjemah. Alkaf, Abdullah Zaki, (Bandung: Hasyimi Press, 2004), 502.

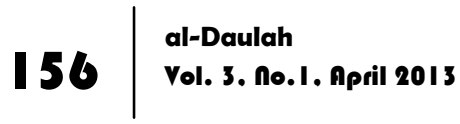


terhadap kramanya. Tak jauh berbeda dengan hasil dari penarikan jizyah yang juga menjadi pemasukan bagi kas negara dan dipergunakan untuk kepentingan pemerintah Islam kala itu. Hal ini serupa juga dengan pajak yang merupakan iuran dari warga untuk pemerintah dan digunakan demi kepentingan pemerintahan.

Jadi, apa yang dilakukan oleh Banjar Adat/Desa Pakraman dengan menerapkan pungutan dana krama tamiu terhadap penduduk pendatang bisa dikatakan sebagai bentuk reinkarnasi dari konsep jizyah yang pernah diberlakukan oleh Islam.

\section{Implikasi dari Pungutan Dana krama tamiu bagi Penduduk Pendatang di Kec. Klungkung Kab. Klungkung-Bali Perspektif Siyasah Shar'iyyah}

Islam dengan etikanya yang luhur telah menjamin hak-hak asasi semua manusia, baik muslim maupun non-muslim, pribumi maupun asing, baik yang menyangkut hak umum maupun hakhak khusus mereka. Namun, para ahli hukum negara sepakat bahwa harus ada bagian kecil dari hak-hak yang harus dimiliki orang asing dalam suatu negara. Bagian terkecil itu disebut sebagai batas terendah dari suatu hak. Adapun batas terendah itu adalah :55

1. Pengakuan orang asing terhadap karakteristik hukum, atau hukum yang menjamin terlaksananya proses hukum yang selayaknya bagi kehidupan individu.

2. Pengakuan bagi orang asing atas hak-hak yang diperolehnya di wilayah negara sesuai dengan hukum perundang-undangan yang berlaku di negara tersebut.

3. Pengakuan bagi orang asing terhadap kebebasan yang selayaknya dibutuhkan oleh karakteristik manusia, seperti kebebasan aqidah, kebebasan menjalankan agama dengan terbuka dalam batas peraturan umum dan etika, 
kebebasan individu dalam kebaikan dan peraturan umum, etika umum, kebenaran umum, darurat perang, juga kebebasan tempat tinggal dan

4. migrasi dalam batas hukum itu.

5. Setiap negara maju mengakui bagi orang asing atas hakhak mendapatkan keadilan di depan hukum.

6. Orang asing mempunyai hak untuk membela negara yang didiaminya.

Bila melihat terhadap penerapan pungutan dana krama tamiu yang diterapkan oleh Banjar Adat/Desa Pakraman, maka sudah ada implikasi yang jelas terhadap hak-hak dari penduduk pendatang.

Pengayoman dari segala macam bahaya (pasayuban sakala, pasayuban kapancabayan), seperti pertolongan bila terjadi musibah, seperti hanyut karena banjir, kebakaran, pencurian, penganiayaan, merupakan salah satu dari bentuk implikasi tersebut.

Pengawasan dan perlindungan keamanan yang dilakukan oleh petugas keamanan banjar adat yaitu pecalang atau langlang merupakan bentuk dari implikasi yang lain. Pengawasan dan perlindungan keamanan ini meliputi banyak hal, baik keamanan diri maupun keamanan ritual keagamaan yang dijalaninya. Seperti perlindungan saat menjalankan upacara keagamaan dll.

Selain itu, mereka juga berhak mendapatkan pelayanan kesehatan dan pengobatan gratis serta berhak menggunakan fasilitas Banjar Adat/Desa Pakraman apabila krama tamiu memiliki hajatan atau mengadakan kegiatan keagamaan.

Berbagai bentuk implikasi yang diberikan Banjar Adat/Desa Pakraman terhadap penduduk pendatang yang dikenai pungutan dana krama tamiu, membuktikan bahwa banjar adat memang bertanggung jawab terhadap krama tamiu yang menjadi tanggungannya dan berada dalam pengawasan serta perlindungannya.

Bila demikian bentuk implikasi dan hak yang dapat diterima oleh penduduk pendatang, maka hal ini tidak berbeda dengan pemerintahan Islam ketika memberlakukan jizyah terhadap ahl al- 
zimmah. Mereka juga mendapatkan hak-hak yang hampir sama seperti jaminan atas kebebasan pribadi, diantaranya : kebebasan berhak milik, kebebasan bertempat tinggal, kebebasan berusaha dan bekerja, kebebasan berpendapat, kebebasan beragama (aqidah), dan kebebasan belajar dan berkreasi. Selain dari adanya jaminan kebebasan pribadi, Islam juga memberikan jaminan sosial dan jaminan keamanan terhadap ahl al-zimmah.

Melihat dari implikasi yang diberikan, antara Banjar Adat/Desa Pakraman dengan pemerintahan Islam hampir tidak ada perbedaan. Keduanya memberikan perlindungan yang sama terhadap mereka yang menjadi tanggungannya. Hanya saja implikasi dari pungutan dana krama tamiu tersebut tidak serta merta dirasakan oleh semua penduduk pendatang seperti pengawasan dan perlindungan keamanan. Karena masih adanya kecemasan penduduk pendatang terhadap gangguan dari kalangan tertentu yang sering melakukan mabuk-mabukan di lingkungan sekitar Banjar Adat. Hal inilah yang berbeda dengan jaminan keamanan dari pungutan jizyah. Dalam konsep Siyasah Shar'iyyah, bila seseorang telah membayar jizyah maka orang tersebut mendapatkan perlindungan keamanan secara total dari pemerintahan Islam. Bahkan karena begitu berharganya, Islam juga menegaskan bahwa darah dan jiwanya pun diharamkan untuk dibunuh. Begitu tingginya Islam memberikan perlindungan terhadap ahl. al-zimmah yang telah membayar jizyah. Namun, secara umum hak-hak dari penduduk pendatang telah diberikan oleh banjar adat sebagai bentuk implikasi dari adanya pungutan dana krama tamiu tersebut.

Selain mendapatkan kebebasan pribadi, jaminan sosial, dan jaminan keamanan, ahl al-zimmah sebagai kaum minoritas dalam negara Islam juga mendapatkan hak-hak lainnya, seperti mendapatkan lahan pekuburan bagi jenazah, hak politik untuk menempatkan wakilnya di dewan perwakilan, dan hak menjalankan ajaran agamanya terkait dengan sembelihan, hijab 
dan lainnya. ${ }^{56}$ Begitu juga yang terjadi di Kecamatan Klungkung, hal yang sama juga diberikan terhadap penduduk pendatang, walaupun tidak secara keseluruhan.

Hasil dari pungutan dana krama tamiu tersebut juga digunakan untuk membayar pecalang, untuk upacara adat, perbaikan jalan dan pura serta untuk kepentingan Banjar Adat/Desa Pakraman dalam menjalankan tugasnya sebagai bagian dari pemerintahan adat di Kecamatan Klungkung.

Hal ini juga serupa dengan pemerintahan negara Islam, sebagaimana diterangkan Muhammad Iqbal bahwa sebagian dari hasil pungutan Jizyah tersebut juga digunakan untuk pembiayaan kepentingan tentara Islam dalam mempertahankan dan membela negara Islam dari serangan musuh. ${ }^{57}$

Jadi, secara substansial apa yang dilakukan Banjar Adat/Desa Pakraman dengan menerapkan pungutan dana krama tamiu tersebut sudah ada implikasinya yang jelas dan hal ini serupa dengan konsep jizyah dalam pemerintahan Islam. Sehingga manfaatnyapun lebih besar bisa dirasakan oleh penduduk pendatang umumnya dan mereka yang beragama Islam khususnya.

\section{Penutup}

Penduduk pendatang di Kec. Klungkung Kab. KlungkungBali dikenai penerapan pungutan dana krama tamiu oleh Banjar Adat/Desa Pakraman yang besarnya antara Rp. 5.000,- sampai Rp. 10.000 ,- perkeluarga dengan ketentuaan berada pada masingmasing Banjar Adat/Desa Pakraman.

Proses penarikan pungutan dana krama tamiu tersebut dilakukan setiap bulan oleh petugas keamanan Banjar Adat/Desa Pakraman yaitu pecalang. Penerapan pungutan dana krama tamiu

\footnotetext{
56 Muhammad, Jamaluddin Athiya, Figh Baru bagi Kaum Minoritas, HAM dan Supremasi Hukum sebagai Keniscayaan, 231.

57 Muhammad lqbal, Figh Siyasah, Kontekstualisasi Doktrin Politik Islam, (Jakarta: Gaya Media Utama, 200 I), 278.
} 
tersebut tertuang dalam aturan petunjuk teknis pelaksanaan pendaftaran penduduk pendatang yang dihasilkan pada rapat kerja Kependudukan Tingkat Kabupaten Klungkung tanggal 1 Juli 2004 yang mengacu pada kesepakatan bersama Gubernur Bali dengan Bupati/Walikota se-Bali No. 153 Tahun 2003 dan instruksi Bupati Klungkung Nomor 268 Tahun 2003.

Sedangkan hak-hak yang bisa didapatkan oleh mereka adalah jaminan keamanan, pelayanan kesehatan, pengayoman dari bencana, dan penggunaan fasilitas Banjar Adat. Namun, jaminan keamanan tidak serta merta dapat dirasakan oleh semua penduduk pendatang. Karena masih adanya kehawatiran penduduk pendatang terhadap kelompok-kelompok pemuda yang sering mabuk-mabukan di wilayah sekitar banjar, sedangkan pihak banjar sendiri belum sepenuhnya mengawasi dan mengambil tindakan tegas kepada mereka.

Dalam konsep Siyasah Shar'iyyah tidak dikenal adanya pungutan dana krama tamiu. Akan tetapi dalam sejarah pemerintahan Islam sudah mengenal konsep jizyah, pungutan yang diambil dari ahl al-zimmah sebagai jaminan atas keamanan diri mereka, sebagaimana disebutkan dalam al-Quran surat atTaubah ayat 29. Secara substansial pungutan dana krama tamiu dengan jizyah memang berbeda, namun ada beberapa kesamaan yang bisa dilihat, terutama hak-hak yang diberikan kepada mereka.

Maka ditinjau dari konsep Siyasah Shar'iyyah, apa yang dilakukan oleh Banjar Adat/Desa Pakraman terhadap penduduk pendatang dengan memungut dana krama tamiu tidak jauh berbeda dengan konsep jizyah dalam Islam dari sudut pandang penerapannya dan implikasi yang jelas dari pungutan tersebut. Walaupun ada beberapa persyaratan khusus yang harus dipenuhi oleh penduduk pendatang yang berbeda dengan syarat bagi ahl alzimmah. Namun dengan melihat hak-hak yang diberikan, maka penarikan pungutan dana krama tamiu tersebut bisa dibenarkan. Demi menjaga keamanan dan keberlangsungan hidup penduduk 
pendatang sebagai kelompok minoritas di Kec. Klungkung Kab. Klungkung-Bali.

\section{Daftar Pustaka}

Abd al-Wahab Khalaf, Politik Hukum Islam, Yogyakarta, PT. Tiara Wacana Yogya, 1994.

Ahmad Zaki Yamani, Syariat Islam yang Kekal dan Persoalan Masa Kini, Jakarta Selatan, PT Intermasa, 1977.

Aliyah Samir, Sistem Pemerintahan, Peradilan $\mathcal{E}$ Adat dalam Islam, Jakarta, Khalifa, 2004.

Astiti Tjok Istri Putra, Pemberdayaan Awig-awig Menuju Ajeg Bali,

Lembaga Dokumentasi dan Publikasi Hukum Universitas Udayana, 2005.

Djazuli, Fiqh Siyasah, Jakarta, Kencana, 2007.

Imam Ghozali Said, Laporan Kegiatan Lokakarya Penyusunan Pola Pemeliharaan Kerukunan Umat Beragama Melalui Peran FKUB, Bogor, 2009.

Muhammad al-Allamah, Rahmah al-Ummah fi Ikhtilaf al-A'immah, diterjemah. Alkaf, Abdullah Zaki, Bandung : Hasyimi Press, 2004.

Muhammad Iqbal, Figh Siyasah, Kontekstualisasi Doktrin Politik Islam, Jakarta, Gaya Media Utama, 2001.

Muhammad Jamaluddin Athiya, Figh Baru bagi Kaum Minoritas, HAM dan Supremasi Hukum sebagai Keniscayaan, Bandung, Marja, 2006.

\section{Lembaga}

Departemen Agama Kecamatan Klungkung, data terakhir tahun 2007

Departemen Agama RI, al-Quran dan Terjemahannya, Surabaya : AlHidayah, 1998.

-------, Ensiklopedi Islam di Indonesia, jilid II, Jakarta, CV Anda Utama, 1993. 
Dinas Tenaga Kerja Kependudukan dan Catatan Sipil Kabupaten Klungkung, Laporan Penduduk Kecamatan Klungkung Bulan April 2009

--------, Petunjuk Teknis Tentang Pelaksanaan Pendaftaran Penduduk Pendatang di Kabupaten Klungkung,

Pemerintah Kabupaten Klungkung, Profil Kabupaten Klungkung, Kecamatan Klungkung, 2009.

\section{Peraturan Pemerintah}

Keputusan Pesamuan (rapat) Majelis Desa Pakraman Provinsi Bali Nomor 050/KEP/PSM-1/MDP BALI/III/2006 tanggal 3 maret 2006.

Kesepakatan Bersama Gubernur Bali dengan Bupati/Walikota seBali Nomor 153 Tahun 2003.

Perda Provinsi Bali No 3 Tahun 2001 tentang Desa Pakraman.

\section{Majalah}

Majalah Aula, edisi Mei tahun 2007

\section{Internet}

http://inventarisasi-

pengetahuan.blogspot.com/2007/07/reformulasi-zakatdanpajak-dalam.html

http://www.e-banjar.com/content/view/299

http://www.e-banjar.com/content/view/66/361/lang,en/

http://www2.kompas.com/kompascetak/0301/07/daerah/72312.htm

http;//dsniamanah.or.id/web/content/view/110/1/ 